\title{
Standardising distance sampling surveys of parrots in New Caledonia
}

\author{
Andrew Legault $\cdot$ Jörn Theuerkauf $\cdot$ Emilie Baby $\cdot$ Laetitia Moutin • \\ Sophie Rouys • Maurice Saoumoé $\cdot$ Ludovic Verfaille $\cdot$ Nicolas Barré $•$ \\ Vivien Chartendrault $\cdot$ Roman Gula
}

Received: 10 September 2010/Revised: 20 April 2012/Accepted: 25 May 2012/Published online: 1 July 2012

(C) The Author(s) 2012. This article is published with open access at Springerlink.com

\begin{abstract}
Standardised surveys are essential for monitoring populations and identifying areas that are critical for conservation. With the aim of developing a standardised method of surveying parrots in the rainforests of New Caledonia, we used distance sampling to estimate densities of New Caledonian Parakeets (Cyanoramphus saisseti), Horned Parakeets (Eunymphicus cornutus), Ouvéa Parakeets (E. uvaeensis), and New Caledonian Rainbow Lorikeets (Trichoglossus haematodus deplanchii). We carried out surveys in the early morning and late afternoon, when parrots were easiest to detect. To minimise errors associated with estimating distances and flock sizes by ear, we conducted brief searches to locate parrots, then measured their distance from the transect line. We recorded birds in flight and consider these records to be
\end{abstract}

Communicated by T. Gottschalk.

A. Legault

School of Zoology, University of Tasmania, Private Bag 5,

Hobart, TAS 7001, Australia

e-mail: alegault@utas.edu.au

A. Legault $\cdot$ J. Theuerkauf $(\varangle) \cdot$ R. Gula

Museum and Institute of Zoology, Polish Academy of Sciences,

Wilcza 64, 00-679 Warsaw, Poland

e-mail: jtheuer@miiz.eu

R. Gula

e-mail: rgula@miiz.eu

E. Baby $\cdot$ L. Moutin · S. Rouys

Conservation Research New Caledonia, BP 2549,

98846 Nouméa Cedex, New Caledonia

e-mail: emilie.baby@sco.asso.nc

L. Moutin

e-mail: 1moutin@gmail.com

S. Rouys

e-mail: sophierouys@gmail.com important when estimating parakeet populations. In agreement with existing knowledge on distance sampling, we found line transects to be more efficient than point transects for estimating the density of parakeets. Our results indicate that parrots located beyond $50-70 \mathrm{~m}$ from the transect line have little influence upon density estimates. In addition, surveys on roads are likely to underestimate densities if not corrected for road width. We generated relatively stable and precise density estimates $(\mathrm{CV}<0.25)$ with approximately $40-50$ detections, yet additional effort may be warranted under different study conditions. Although we aimed to improve parrot surveys in New Caledonia, our suggestions may be useful to other researchers studying rainforest birds, and can be adapted to suit different species or environments.

Present Address:

E. Baby $\cdot$ S. Rouys

Société Calédonienne d'Ornithologie, BP 13641,

98803 Nouméa Cedex, New Caledonia

M. Saoumoé · L. Verfaille

Province des Iles Loyauté, Direction du Développement

Economique, BP 50, 98820 Wé, Lifou, New Caledonia

e-mail: m-saoumoe@loyalty.nc

L. Verfaille

e-mail: seimelo@no-log.org

N. Barré · V. Chartendrault

Institut Agronomique néo-Calédonien (IAC/CIRAD),

BP 73, 98890 Païta, New Caledonia

e-mail: belairbarre@hotmail.fr

V. Chartendrault

e-mail: vivienpiou@yahoo.fr 
Keywords Conservation - Distance sampling . New Caledonia $\cdot$ Parrots $\cdot$ Survey methods

\section{Zusammenfassung}

\section{Standardisierung von „Distance Sampling“ zur Erfassung von Populationsdichten der Papageien Neukaledoniens}

Standardisierte Erhebungen sind wichtig für die Überwachung von Populationsentwicklungen und die Erfassung von Bereichen, die für die Arterhaltung von entscheidender Bedeutung sind. Mit dem Ziel, eine standardisierte Methode zur Erfassung von Papageien der Regenwälder Neukaledoniens zu entwickeln, haben wir mit Hilfe von „Distance Sampling " Bestände von Neukaledoniensittichen (Cyanoramphus saisseti), Hornsittichen (Eunymphicus cornutus), Ouvéa-Sittichen (E. uvaeensis) und Neukaledonien-Allfarbloris (Trichoglossus haematodus deplanchii) geschätzt. Wir führten die Zählungen am frühen Morgen und späten Nachmittag durch, wenn Papageien am leichtesten zu entdecken sind. Um Fehler bei der Schätzung von Entfernungen und Gruppengrößen per akustischem Wahrnehmen zu minimieren, haben wir die Papageien schnell gesucht und dann ihre Entfernung zur Transektlinie gemessen. Wir haben fliegende Vögel gleichfalls notiert und denken, dass diese ebenfalls in Schätzungen der Sittich-Populationsdichte eingehen sollten. In Übereinstimmung mit anderen Arbeiten über „Distance Sampling“ fanden wir, dass zur Dichteschätzung der Sittiche Linientransekte effizienter als Punkttransekte sind. Unsere Ergebnisse zeigen, dass Beobachtungen von Papageien, die über 50-70 $\mathrm{m}$ von der Transektlinie entfernt waren, wenig Einfluss auf die Dichteschätzungen haben. Darüber hinaus unterschätzen Zählungen entlang von Straßen die Populationsdichte, wenn die Fahrbahnbreite nicht zur Korrektur der Entfernungen zur Transektlinie hinzugezogen wird. Wir haben relativ stabile und präzise geschätzte Dichten $(\mathrm{CV}<0,25)$ mit etwa 40-50 Beobachtungen ermittelt, jedoch könnten unter abweichenden Studienbedingungen weitere Beobachtungen nötig sein. Obwohl es unser Ziel war, Populationsdichteschätzungen der Papageien in Neukaledonien zu verbessern, können unsere Vorschläge nützlich für Dichteschätzungen anderer Regenwaldvögel sein und entsprechend für andere Arten oder Lebensräume angepasst werden.

\section{Introduction}

Population estimates play a critical role in identifying species that require protection, and in setting priorities for conservation (IUCN 2011), yet obtaining reliable estimates remains an elusive task for certain taxa (Cassey et al. 2007). One of the most commonly used methods to approximate animal abundance is index counting, where the observer records the number of individuals detected around a point, or along a transect (Rosenstock et al. 2002), usually over a defined time period. Fauna monitoring programs are often dependent upon such indices, as they are useful for comparing temporal and spatial patterns of abundance (Karubian et al. 2005), and gauging population growth or decline (Amar et al. 2008). In spite of this, indices only provide a relative measure of abundance, and do not account for the conspicuousness of the species under study, variations in the surrounding environment, or the differing skills of observers (Cassey et al. 2007).

Although indices can play an important role in wildlife surveys (Hutto and Young 2003; Johnson 2008), approaches that consider the detectability of the species under study are often considered more appropriate, particularly when the goal is to estimate absolute numbers (Rosenstock et al. 2002; Thompson 2002; Norvell et al. 2003). Examples of these survey techniques include variable strip transects (Emlen 1971, 1977), variable circular plots (Reynolds et al. 1980), double-observer sampling (Nichols et al. 2000), independent-observer methods (Alldredge et al. 2006), and time-of-detection approaches (Farnsworth et al. 2002; Alldredge et al. 2007a). The method most commonly used to account for detectability is distance sampling, where the observer measures the distance to each animal (or group of animals) detected from a point or transect line (Burnham et al. 1980; Buckland et al. 1993, 2001). The distances are then used to calculate the probability of encountering an animal as a function of distance from the transect line. Because the probability of detection declines in a quantifiable and predictable manner, the detection function can be used to estimate the number of animals within the area that was effectively surveyed. Distance sampling is advantageous in this regard, as it provides an approximation of animal density, yet it does not require the detection of all individuals present, or prior knowledge of the size of the area sampled. The method is based on the assumption that individuals on the line or point are detected with certainty, individuals are detected at their initial location, and distances are measured exactly. All of these assumptions may be relaxed under certain circumstances (Buckland et al. 1993; Thomas et al. 2010), although the reliability of estimates may suffer if they are not met (Bächler and Liechti 2007).

Distance sampling has been used to survey a variety of fauna, and is often employed in bird surveys. It is generally less intrusive than alternative methods such as mist netting (e.g. Meyers 1994; Whitman et al. 1997) and markrecapture (e.g. Sandercock and Beissinger 2002), and 
provides an efficient means of estimating abundance when it is not feasible to conduct plot searches (e.g. RodriguezEstrella et al. 1992) or roost counts (e.g. Gnam and Burchsted 1991). In studies of parrots, distance sampling has proven useful for estimating population size (e.g. Walker and Cahill 2000; Rivera-Milán et al. 2005), assessing abundance in different habitats (e.g. Marsden et al. 2001; Marsden and Symes 2006), and evaluating conservation actions (e.g. Jepson et al. 2001; Barré et al. 2010). However, little consideration has been given to the application of distance sampling techniques for surveying birds in tropical rainforests, in spite of the fact that methods that work in other locations may need to be adapted to suit rainforest conditions (Raman 2003; Buckland et al. 2008; Lee and Marsden 2008; Gale et al. 2009). Rainforest birds are often cryptic and difficult to spot amongst the dense vegetation, so researchers frequently rely upon aural cues to estimate distances (e.g. Marsden et al. 2006; Gale et al. 2009). Difficult terrain can also make it impractical to place transects randomly, thus surveys are occasionally conducted along roads or trails (e.g. Jones et al. 1995; Marsden 1999; Gale and Thongaree 2006; Lee and Marsden 2008), or other non-random features such as ridges (e.g. Simon et al. 2002). Temporal variations in detectability can also pose problems when surveying tropical forest birds, therefore survey periods may need to be carefully regimented (Marsden 1999; Simon et al. 2002; Buckland et al. 2008).

In New Caledonia, few attempts have been made to estimate the abundance of rainforest birds (Chartendrault and Barré 2005, 2006). Density estimates have played a key role in monitoring the population of endangered (IUCN 2011) Ouvéa Parakeets Eunymphicus uvaeensis (Avibase ID: 7CF9DDC2A21A1D9A; http://avibase.bsceoc.org), and in evaluating the consequences of parakeet conservation programs on Ouvéa (Barré et al. 2010). However, the parakeets of mainland New Caledonia have received comparatively little attention, despite the fact that New Caledonian Parakeets Cyanoramphus saisseti (Avibase ID: 75F9612EBA158702) and Horned Parakeets E. cornutus (Avibase ID: FC7AB945C8292D66) are both categorised as vulnerable by the IUCN (2011). Anecdotal evidence suggests that populations of mainland parakeets have fallen over the past century (Layard and Layard 1882; Bregulla 1993; Hahn 1993). Although these accounts provide cause for concern, there are almost no field data available to determine the extent of such declines. In the absence of detailed information about parakeet populations, it is difficult to detect population trends or identify critical areas for conservation.

The primary aim of this research was to develop and test a standardised method for estimating parrot density in New Caledonia, so that populations can be monitored effectively. Standardised methods of surveying are essential for comparing parrot populations across different time frames or geographical regions as the resulting data can be interpreted with much greater confidence than data collected using an assortment of different techniques. Using distance sampling, we surveyed New Caledonian Parakeets, Horned Parakeets, and New Caledonian Rainbow Lorikeets Trichoglossus haematodus deplanchii (Avibase ID: E3C3CC2E71949308), which are endemic to mainland New Caledonia, and Ouvéa Parakeets, which are endemic to the neighbouring island of Ouvéa. In doing so, we attempted to find a balance between efficient and accurate counts by modifying various elements of our survey design to suit the conditions encountered in New Caledonian rainforests. We assessed whether line transects or point transects are likely to be more appropriate for surveying parakeets in New Caledonia, and established the amount of effort required to achieve a suitable level of confidence in each density estimate. Additionally, we analysed the relationship between the relative abundance and absolute density of parakeets on the mainland in order to increase the utility of existing indices.

\section{Methods}

Study areas and focal species

Our study sites were located at three locations in New Caledonia (Fig. 1): Parc Provincial de la Rivière Bleue (PPRB; $22^{\circ} 07^{\prime} \mathrm{S}, 166^{\circ} 40^{\prime} \mathrm{E}$ ), Parc des Grandes Fougères (PGF; $21^{\circ} 37^{\prime} \mathrm{S}, 165^{\circ} 46^{\prime} \mathrm{E}$ ), and the island of Ouvéa $\left(20^{\circ} 36^{\prime} \mathrm{S}, 166^{\circ} 34^{\prime} \mathrm{E}\right)$. All three sites have been recently designated as 'Important Bird Areas' as they provide valuable habitat for parakeets and other threatened bird species (Spaggiari et al. 2007).

PPRB is a $90 \mathrm{~km}^{2}$ reserve located in the south of New Caledonia. We carried out our research in the valley of the Rivière Bleue (Theuerkauf et al. 2009). Around $93 \%$ of the vegetation at the study site is rainforest, and the remaining $7 \%$ is maquis (shrubland). The mean annual rainfall in the Rivière Bleue valley is $3,200 \mathrm{~mm}$, which makes it one of the wettest lowland areas in New Caledonia (Bonnet de Larbogne et al. 1991).

PGF is a $45 \mathrm{~km}^{2}$ reserve located near the centre of New Caledonia. The vegetation at the study site consists of approximately $68 \%$ rainforest, $22 \%$ secondary regrowth (a mix of young forest and savannah), and $10 \%$ scrub and pine plantations. The mean annual rainfall in the region is 1,800 mm (Jaffré and Veillon 1995).

Ouvéa is a $130 \mathrm{~km}^{2}$ raised coral atoll located approximately $100 \mathrm{~km}$ northeast of mainland New Caledonia. A narrow isthmus connects the north and south of the island. 


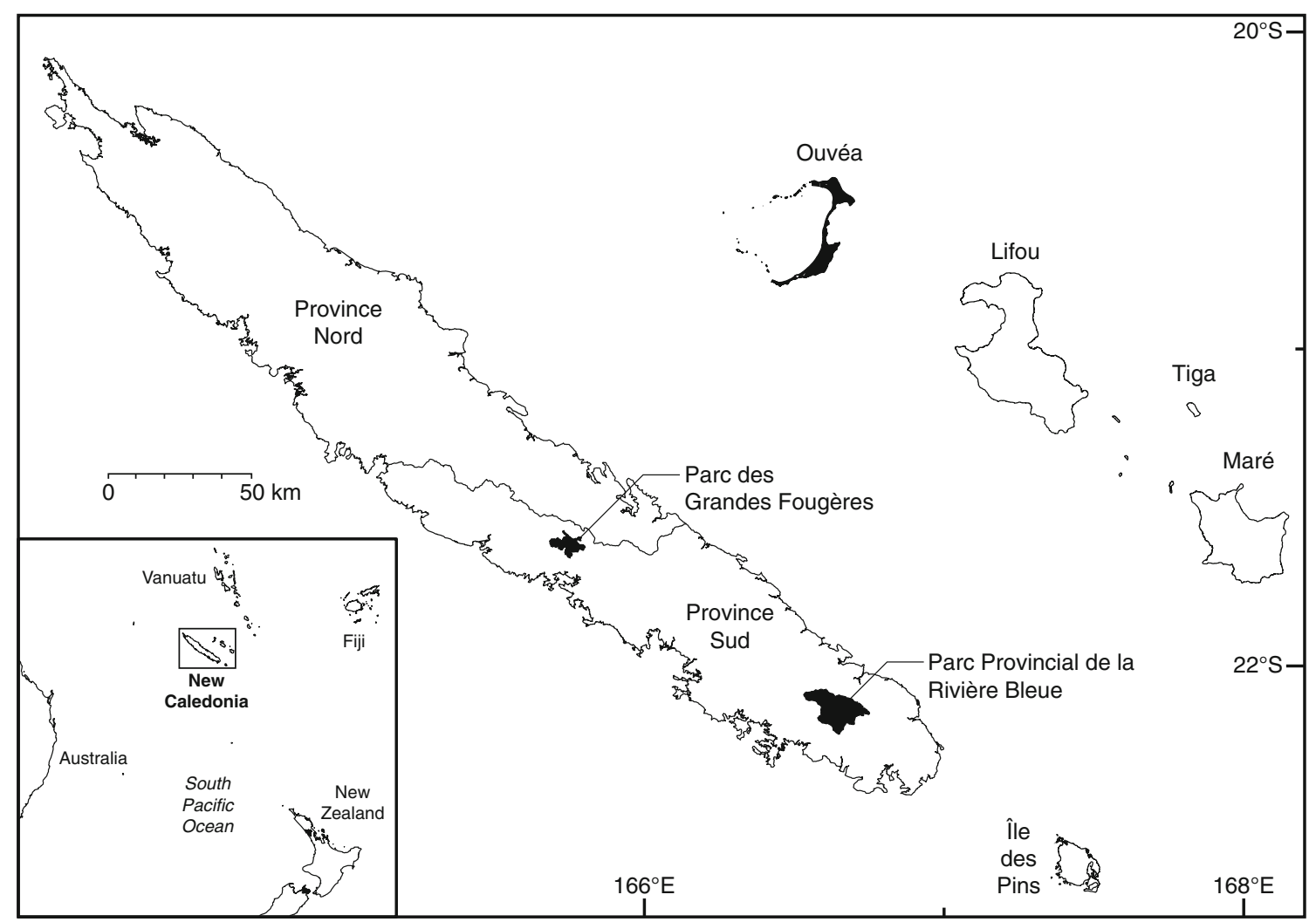

Fig. 1 New Caledonia, including the location of study areas (in black)

The vegetation at the study site consists of approximately $90 \%$ rainforest and $10 \%$ plantations (mainly of coconut). The island receives an average annual rainfall of $1,250 \mathrm{~mm}$ (Barré et al. 2010).

All of the parrots we studied are mostly green, mediumsized birds, yet the vocalisations of each species are distinct. Rainbow Lorikeets occasionally form large flocks containing dozens of birds, but New Caledonian Parakeets, Horned Parakeets, and Ouvéa Parakeets rarely occur in flocks of more than three or four birds (Barré et al. 2010; Legault et al. 2012). Introduced Pacific Rats Rattus exulans, Black Rats Rattus rattus, and Feral Cats Felis catus are considered to be predators of parrots in New Caledonia (Robinet et al. 1998; Gula et al. 2010). All of these species inhabit the study areas on mainland New Caledonia (Rouys and Theuerkauf 2003), and all but the Black Rat are present on Ouvéa (Robinet et al. 1998). Although parakeet poaching has been an issue on Ouvéa in the past (Robinet et al. 1996), it is unlikely to have been an important factor over the period of our study (Pain et al. 2006; Barré et al. 2010).

\section{Surveys}

We used distance sampling (Buckland et al. 1993, 2001) to carry out line transect surveys at each of the study sites.
Surveys were conducted by multiple observers as we were interested in developing methods that would allow monitoring to continue indefinitely. A pair of observers undertook 25 surveys along a $5.4 \mathrm{~km}$ transect at PPRB from November 2004 to January 2005. Two other individuals conducted 30 surveys along the same transect from March to June 2008. Another observer carried out 31 surveys along a $5.1 \mathrm{~km}$ transect at PGF from January to March 2009. It took approximately $2.5 \mathrm{~h}$ to complete each of these surveys. We collected additional data at both of these sites in order to compare different distance sampling techniques, as specified in the following section. Several groups of observers conducted surveys on the island of Ouvéa in December 2008, December 2009, and August 2011. Most of these groups were comprised of two or three individuals. Transects ranged in length from approximately $1-12 \mathrm{~km}$, and followed similar routes each year, although we added several new transects in 2009 and 2011. We surveyed $163 \mathrm{~km}$ of transects in total, including $77 \mathrm{~km}$ (23 transects) in the north of Ouvéa, and $87 \mathrm{~km}$ (17 transects) in the south. The main purpose of these surveys was to estimate densities in the north and south of the island using a standardised methodology. We did not record Rainbow Lorikeets during surveys on Ouvéa or at PGF because the results of the initial survey at PPRB suggested that the 
transient nature of this species would pose difficulties in estimating local abundance, and there is only a small, introduced population of Rainbow Lorikeets on Ouvéa (Barré et al. 2010).

In May of 2008, we tested point transect distance sampling (Buckland et al. 1993; Thomas et al. 2002) at PPRB to see how this method compared to line transect distance sampling in practice. We selected 24 points along the $5.4 \mathrm{~km}$ path that we used for line transects. Each point was $200 \mathrm{~m}$ apart, and we spent 3 min listening for parrots at each one. We carried out point transect surveys during the afternoon because mornings were dedicated to line transect surveys. From start to finish, it took approximately $2 \mathrm{~h}$ to survey each transect (including travel between points). We only conducted six point transect surveys as we found line transects to be more effective for surveying parakeets.

Line transect survey method

During surveys, we found it was practical to have at least two observers, so that tasks could be shared. However, some of the surveys were carried out by a single observer due to limitations in the availability of field workers. We mainly followed tracks or dirt roads, and sometimes a compass bearing through forest (on Ouvéa). For the most part, the tracks were narrow routes through rainforest. The dirt access road at PPRB was approximately 4-8 m wide, although some parts were covered entirely by the forest canopy, and several short sections of the road were cleared of vegetation beyond $10 \mathrm{~m}$. We usually walked transects between 0.5 and $3 \mathrm{~h}$ after dawn, but for testing purposes, we surveyed about half of the transects at PGF in the afternoon, from 3 to $0.5 \mathrm{~h}$ before dusk. To increase sampling efficiency, we also surveyed half of the Ouvéa transects in the afternoon. We chose these periods of the day as they are when parrots are most active in New Caledonia (Robinet et al. 2003; Legault et al. 2012).

In order to maximise the probability of detecting birds near the transect line, we only carried out surveys in fair weather (i.e. no rain or strong wind), and walked each transect at a slow pace (around $2 \mathrm{~km}$ per hour). We walked quietly during surveys so that birds could be easily detected, and listened for the sounds of wings flapping or parrots chattering. Whenever we saw or heard parrots, we made our way to their location as quickly as possible. We noted the number of birds, and measured the perpendicular distance (to the nearest metre) from the centre of the flock to the transect line using a measuring tape. Due to the difficulty in spotting parrots, it was occasionally necessary to take measurements from the tree where the calls came from. We only spent a few minutes searching for birds in order to reduce the likelihood of them moving prior to being located. If we suspected movement during the search period, or if we could not locate parrots during searches, then we estimated their original location based on their calls. In addition, we recorded the GPS coordinates (WGS 84, UTM) of each parrot or flock detected.

We recorded flying birds at the location where we first saw them, and paid attention to their flight path in order to minimise the possibility of counting them twice along the same transect. During surveys at PPRB and PGF, we noted whether parrots were flying or perched in order to compare densities with and without birds in flight. In addition, we estimated the height of birds detected during surveys at these sites. If the height of birds influenced detectability, we would not expect the detections to be normally distributed with respect to height. Therefore, we tested the height data for normality using a Kolmogorov-Smirnov test. At PPRB, we also measured the width of the road at each point of detection in order to compensate for the lack of habitat above the road.

\section{Analyses}

We analysed the distance sampling data with Distance 6.0, Release 2 (Thomas et al. 2010). We used the program's default CDS (Conventional Distance Sampling) engine, which analyses transect data using an approach described by Buckland et al. (1993, 2001). We used exact distance measurements and cluster sizes to estimate densities. We calculated the variance of each density estimate empirically, based on the variance in observations between samples. To compensate for potential differences in detectability, we generated separate detection functions for each species at each site. We tried out various combinations of key functions (uniform, half-normal, hazard-rate) and series adjustments (cosine, simple polynomial, hermite polynomial) and used Akaike's Information Criterion (AIC) to evaluate the fit of each model (Thomas et al. 2010). Among the models with the lowest AIC values, we selected the one that appeared most suitable based on a visual examination of histograms and the results of goodness of fit tests (Buckland et al. 1993; Buckland 2006; Thomas et al. 2010).

To facilitate comparison between different treatments, we assigned a truncation distance for each species at each site. We usually used the largest recorded distance for this purpose, though we truncated one or two of the most distant records if it improved the shape of the detection function (Buckland et al. 2001; Thomas et al. 2010). We calculated the density (including $95 \%$ confidence intervals) of parrots after surveying each transect, and plotted these data to determine the number of detections, and length of transects, required for the mean density to stabilise. The aim was to identify the minimum number of detections required to achieve stable density estimates that were approximately equal to those achieved using all detections. Using a fixed 
truncation distance made it easier to evaluate when densities stabilised over the course of the study. Otherwise, we found that densities would change abruptly on days when more distant detections were recorded, as a result of the increased truncation distance and corresponding decrease in detection efficiency (Norvell et al. 2003). We also plotted the relationship between the coefficient of variation $(\mathrm{CV})$ of density estimates and the number of records accumulated for each species at each site. We used a CV of 0.25 to identify an upper threshold of precision for comparing densities at different sites, although a CV of 0.20 or less might be more appropriate for management and monitoring purposes (Buckland et al. 1993). Researchers interested in obtaining the Distance files to carry out comparative analyses are encouraged to contact us.

By analysing the data in various ways, we were able to determine how different survey techniques might influence density estimates. At PGF, we assessed whether the time of day affected densities by comparing morning and afternoon surveys. At PPRB and PGF, we also analysed how the inclusion or exclusion of flying birds influenced densities. To compensate for the presence of the road at PPRB, we subtracted half the width of the road from each detection distance. In doing so, we effectively shifted the centreline to the edge of the road (similar to Heydon et al. 2000). Had we not done this, the records closest to the centreline would have been largely restricted to birds in flight, due to the lack of vegetation over the road.

Conversion between relative abundance and absolute density of parakeets

On several of the days when we surveyed transects at PPRB and PGF, we additionally spent the rest of the day recording observations of New Caledonian Parakeets and Horned Parakeets in forested areas near the transect line. We carried out the equivalent of ten full-day counts at PPRB in 2004/2005, 5 full-day counts at PPRB in 2008, and ten full-day counts at PGF in 2009. This provided us with a measure of the average daily encounter rate $(E)$ and the standard deviation of the daily encounter rate $\left(\mathrm{SD}_{E}\right)$ for parakeets at both of the mainland sites. We undertook these counts in order to determine the relationship between encounter rates and absolute densities of parakeets.

With the absolute density $(D)$ and lower and upper $95 \%$ confidence limits (LCL, UCL) provided by Distance 6.0, we calculated the standard deviation of the absolute density $\left(\mathrm{SD}_{D}\right)$, as follows (modified from Thomas et al. 2002):

$\mathrm{SD}_{D}=\sqrt{\left(\mathrm{e}^{\left.10^{\left(\frac{\log (\ln C / 1.96)}{0.5}\right)}-1\right) \times D^{2}}\right.}$

where
$C=\frac{D}{95 \% L C L}=\frac{95 \% U C L}{D}$

We calculated a coefficient $(K=D / E)$ to convert from relative abundance (i.e. from daily encounter rates) to absolute densities of parakeets (i.e. from line transect distance sampling). In addition, we calculated $95 \%$ confidence intervals for the coefficient based on standard deviations $\left(\mathrm{SD}_{K}\right)$, which we estimated as follows (Theuerkauf et al. 2008; modified from Goodman 1960):

$\mathrm{SD}_{K}=\sqrt{\frac{D^{2} \mathrm{SD}_{E}^{2}+E^{2} \mathrm{SD}_{D}^{2}+\mathrm{SD}_{D}^{2} \mathrm{SD}_{E}^{2}}{E^{4}}}$

We also plotted densities (birds $/ \mathrm{km}^{2}$ ) against encounter rates (birds/day) to verify that their relationship was linear. In order to increase the number of estimates per species, we split each survey period into three consecutive intervals and calculated densities and encounter rates over each interval. To improve the precision of density estimates, we pooled detection functions over consecutive intervals.

\section{Results}

We recorded 651 flocks of parrots during line transect distance sampling surveys in New Caledonia (Table 1). We detected $67 \%$ of the parrots within $20 \mathrm{~m}$ of the transect line, and only $5 \%$ past $50 \mathrm{~m}$. However, detectability varied depending on the species and site (Fig. 2). Detections beyond $50-70 \mathrm{~m}$ generally contributed little to the density estimates (Table 2). In some cases, truncating the most distant records allowed us to model the data more reliably, yet this removed no more than $2.5 \%$ of the detections (at most 2 records) for any given species at any given site (Table 2). Detections of New Caledonian Parakeets $(P=0.582)$ and Horned Parakeets $(P=0.114)$ were normally distributed with respect to height, whereas those of Rainbow Lorikeets $(P=0.007)$ were not.

To achieve relatively stable density estimates of parakeets on the mainland, approximately 15-20 replicate transects were required, or $75-100 \mathrm{~km}$ of transects in total (Fig. 3). By this stage, most of the estimates had reached a plateau, and precision increased slowly with the addition of new transects. The relationship between the coefficient of variation $(\mathrm{CV})$ of density estimates and the number of observations accumulated for each species at each site indicates that $30-40$ observations were usually required to reduce the $\mathrm{CV}$ to 0.25 , and $40-50$ observations were usually required to achieve a $\mathrm{CV}$ of 0.20 (Fig. 4).

Excluding flying birds from the analysis had the greatest effect upon the Rainbow Lorikeet, leading to a $67 \%$ decrease in the 2004/2005 density estimate at PPRB 
Table 1 Average flock size and number of flocks detected $(n)$ during line transect distance sampling of parrots at Parc Provincial de la Rivière Bleue (PPRB), Parc des Grandes Fougères (PGF), and North and South Ouvéa

\begin{tabular}{|c|c|c|c|c|c|c|c|c|c|c|c|c|}
\hline \multirow[t]{2}{*}{ Study site } & \multicolumn{3}{|c|}{ New Caledonian Parakeet } & \multicolumn{3}{|c|}{ Horned Parakeet } & \multicolumn{3}{|c|}{ Rainbow Lorikeet } & \multicolumn{3}{|c|}{ Ouvéa Parakeet } \\
\hline & Mean & SD & $n$ & Mean & SD & $n$ & Mean & SD & $n$ & Mean & SD & $n$ \\
\hline PPRB 2004/05 & 1.4 & 0.6 & 46 & 1.5 & 1.1 & 39 & 2.1 & 1.1 & 100 & & & \\
\hline PPRB 2008 & 1.9 & 1.0 & 40 & 1.9 & 1.1 & 63 & & & & & & \\
\hline PGF & 1.3 & 0.6 & 50 & 1.8 & 1.3 & 92 & & & & & & \\
\hline North Ouvéa & & & & & & & & & & 2.0 & 1.1 & 153 \\
\hline South Ouvéa & & & & & & & & & & 1.8 & 0.9 & 68 \\
\hline Pooled & 1.5 & 0.7 & 136 & 1.8 & 1.20 & 194 & 2.1 & 1.1 & 100 & 2.0 & 1.1 & 221 \\
\hline
\end{tabular}
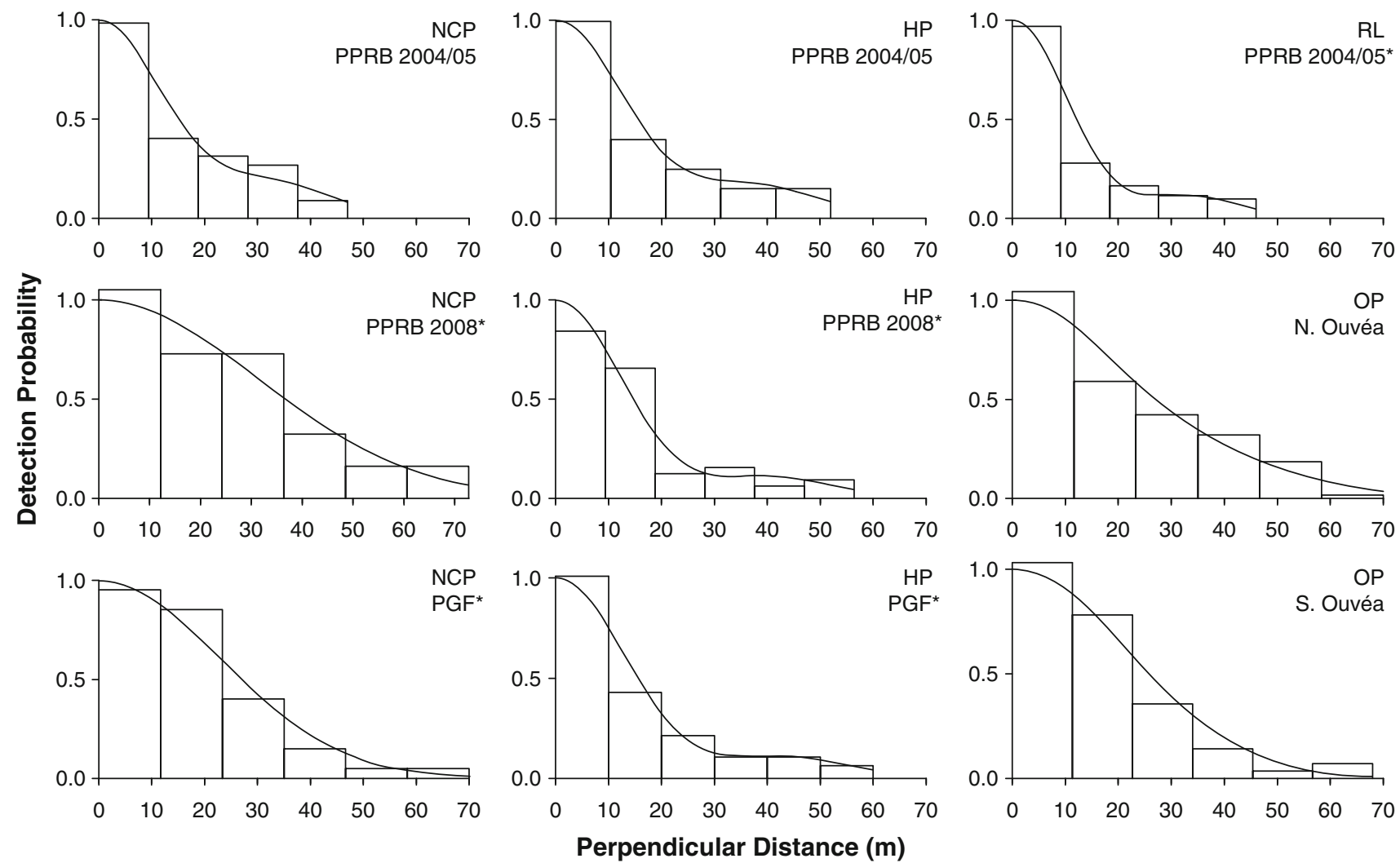

Fig. 2 Detection functions for New Caledonian Parakeets (NCP), Horned Parakeets (HP), Rainbow Lorikeets (RL), and Ouvéa Parakeets (OP) obtained during line transect distance sampling at Parc Provincial de la Rivière Bleue (PPRB), Parc des Grandes

(Table 2). The omission of flying birds reduced density estimates by an average of $19 \%$ for New Caledonian Parakeets, and $7 \%$ for Horned Parakeets (Table 2). The overlap in confidence intervals at each site suggests that these reductions may be irrelevant, although excluding these records slightly decreased the precision of several estimates. Correcting for the width of the road at PPRB increased density estimates by an average of $12 \%$ for New Caledonian Parakeets, $27 \%$ for Horned Parakeets, and $18 \%$ for Rainbow Lorikeets (Table 2). New Caledonian
Fougères (PGF), and North and South Ouvéa. Models marked with an asterisk have been right-hand truncated to achieve a better fit, as specified in Table 2

Parakeet densities were slightly lower during the afternoon than in the morning at PGF, but the sample size was too small to achieve a precise estimate for each period. The estimated density of Horned Parakeets was comparable between morning and afternoon surveys (Table 2).

Assuming a linear relationship between daily encounter rates and densities from line transect distance sampling at PPRB and PGF (Fig. 5), we estimate that a single encounter with a New Caledonian Parakeet per day represents an average density of $1.3(1.2-1.4) \mathrm{birds} / \mathrm{km}^{2}$, and a 
Table 2 Density estimates of New Caledonian Parakeets, Horned Parakeets, Rainbow Lorikeets, and Ouvéa Parakeets from line transect distance sampling at Parc Provincial de la Rivière Bleue (PPRB), Parc des Grandes Fougères (PGF), and North and South Ouvéa, showing the effect of deviating from the 'standard' method, as described in the "Methods"

\begin{tabular}{|c|c|c|c|c|c|c|c|c|c|c|}
\hline Species & Site & Years & Effort (km) & Method & Adjustments & $D(\mathrm{CI})$ & $\mathrm{CV}$ & $n$ & $w$ & ESW \\
\hline \multirow[t]{12}{*}{ New Caledonian Parakeet } & \multirow[t]{7}{*}{ PPRB } & \multirow[t]{3}{*}{$2004 / 05$} & \multirow[t]{3}{*}{135.5} & \multirow[t]{3}{*}{ Standard } & (untruncated) & $13.5(8.6-21.3)$ & 0.23 & 46 & 47 & 19 \\
\hline & & & & & ex. flying birds & $8.4(4.8-14.4)$ & 0.28 & 37 & 47 & 24 \\
\hline & & & & & unadj. road width & $11.8(7.3-19.1)$ & 0.25 & 46 & 50 & 23 \\
\hline & & \multirow[t]{4}{*}{2008} & \multirow[t]{4}{*}{162.6} & \multirow[t]{4}{*}{ Standard } & (truncated) & $6.2(4.2-9.2)$ & 0.20 & 39 & 73 & 38 \\
\hline & & & & & untruncated & $6.0(4.0-8.9)$ & 0.20 & 40 & 78 & 41 \\
\hline & & & & & ex. flying birds & $5.6(3.7-8.5)$ & 0.21 & 37 & 73 & 40 \\
\hline & & & & & unadj. road width & $5.7(3.8-8.5)$ & 0.21 & 39 & 75 & 42 \\
\hline & \multirow[t]{5}{*}{ PGF } & \multirow[t]{5}{*}{2009} & \multirow[t]{5}{*}{158.1} & \multirow[t]{5}{*}{ Standard } & (truncated) & $7.8(5.5-11.2)$ & 0.18 & 49 & 70 & 29 \\
\hline & & & & & untruncated & $9.0(6.0-13.4)$ & 0.20 & 50 & 80 & 26 \\
\hline & & & & & ex. flying birds & $7.1(4.8-10.3)$ & 0.19 & 46 & 70 & 29 \\
\hline & & & & & ex. afternoons & $9.3(5.9-14.6)$ & 0.22 & 32 & 70 & 29 \\
\hline & & & & & ex. mornings & $6.3(3.7-10.8)$ & 0.26 & 17 & 70 & 29 \\
\hline \multirow[t]{12}{*}{ Horned Parakeet } & \multirow[t]{7}{*}{ PPRB } & \multirow[t]{3}{*}{$2004 / 05$} & \multirow[t]{3}{*}{135.5} & \multirow[t]{3}{*}{ Standard } & (untruncated) & $10.7(6.8-16.8)$ & 0.23 & 39 & 52 & 20 \\
\hline & & & & & ex. flying birds & $8.9(5.4-14.8)$ & 0.26 & 35 & 52 & 22 \\
\hline & & & & & unadj. road width & $8.3(5.1-13.6)$ & 0.25 & 39 & 62 & 26 \\
\hline & & \multirow[t]{4}{*}{2008} & \multirow[t]{4}{*}{162.6} & \multirow[t]{4}{*}{ Standard } & (truncated) & $21.3(15.0-30.1)$ & 0.18 & 62 & 56 & 18 \\
\hline & & & & & untruncated & $20.7(14.6-29.2)$ & 0.18 & 63 & 95 & 19 \\
\hline & & & & & ex. flying birds & $21.6(15.2-30.7)$ & 0.18 & 59 & 56 & 18 \\
\hline & & & & & unadj. road width & $16.9(11.2-25.4)$ & 0.21 & 62 & 60 & 23 \\
\hline & \multirow[t]{5}{*}{ PGF } & \multirow[t]{5}{*}{2009} & \multirow[t]{5}{*}{158.1} & \multirow[t]{5}{*}{ Standard } & (truncated) & $32.1(24.6-42.0)$ & 0.14 & 90 & 60 & 19 \\
\hline & & & & & untruncated & $33.2(25.4-43.3)$ & 0.14 & 92 & 90 & 19 \\
\hline & & & & & ex. flying birds & $30.8(23.3-40.6)$ & 0.14 & 84 & 60 & 19 \\
\hline & & & & & ex. afternoons & $30.6(21.1-44.4)$ & 0.19 & 47 & 60 & 19 \\
\hline & & & & & ex. mornings & $33.6(24.7-45.6)$ & 0.15 & 43 & 60 & 19 \\
\hline \multirow[t]{4}{*}{ Rainbow Lorikeet } & \multirow[t]{4}{*}{ PPRB } & \multirow[t]{4}{*}{$2004 / 05$} & \multirow[t]{4}{*}{135.5} & Standard & (truncated) & $48.7(35.7-66.5)$ & 0.16 & 99 & 46 & 15 \\
\hline & & & & & untruncated & $48.9(35.5-67.4)$ & 0.16 & 100 & 103 & 15 \\
\hline & & & & & ex. flying birds & $15.9(9.0-28.0)$ & 0.29 & 43 & 46 & 24 \\
\hline & & & & & unadj. road width & $41.4(30.0-57.1)$ & 0.16 & 99 & 50 & 18 \\
\hline Ouvéa Parakeet & N. Ouvéa & 2008-2011 & 76.6 & Standard & (untruncated) & $61.4(45.5-82.9)$ & 0.15 & 153 & 70 & 30 \\
\hline & S. Ouvéa & $2008-2011$ & 86.5 & Standard & (untruncated) & $23.8(14.4-39.4)$ & 0.25 & 68 & 68 & 27 \\
\hline
\end{tabular}

$D$ density, $C I 95 \%$ confidence intervals, $C V$ coefficient of variation, $n$ number of detections, $w$ truncation distance, $E S W$ effective strip width, $e x$. excluding, unadj. unadjusted

single encounter with a Horned Parakeet per day represents an average density of $2.3(2.1-2.5)$ birds $/ \mathrm{km}^{2}$ (Table 3). From the six experimental point transect surveys (each with 24 points) conducted at PPRB, we estimated the density of New Caledonian Parakeets and Horned Parakeets to be 3.6 ( $\mathrm{CI}=1.3-10.0 ; \mathrm{CV}=0.46 ; n=7)$, and $12.3(\mathrm{CI}=6.0-25.0 ; \quad \mathrm{CV}=0.32 ; n=8) \quad \operatorname{birds} / \mathrm{km}^{2}$, respectively.

\section{Discussion}

The behaviour of New Caledonian Parakeets, Horned Parakeets, and Ouvéa Parakeets lends them well to distance sampling. They occur in small clusters, their vocalisations are distinct, and they are relatively easy to detect during foraging periods because they often chatter as they feed. Additionally, none of the species appeared to react to our presence when we searched for them. When parakeets do take flight, they often announce their departure with a series of raucous calls, which makes it possible to identify their initial location. They also tend to fly over short distances and usually take short rests between flights. It is likely that many other parrots share these characteristics, and would also be appropriate subjects for distance sampling. Certain species, like the Rainbow Lorikeet, may prove difficult to survey in rainforest, not only due to their swift flight, and the distances they cover, but also due to their highly variable flock sizes. However, we have successfully estimated densities of Blue-crowned Lorikeets 

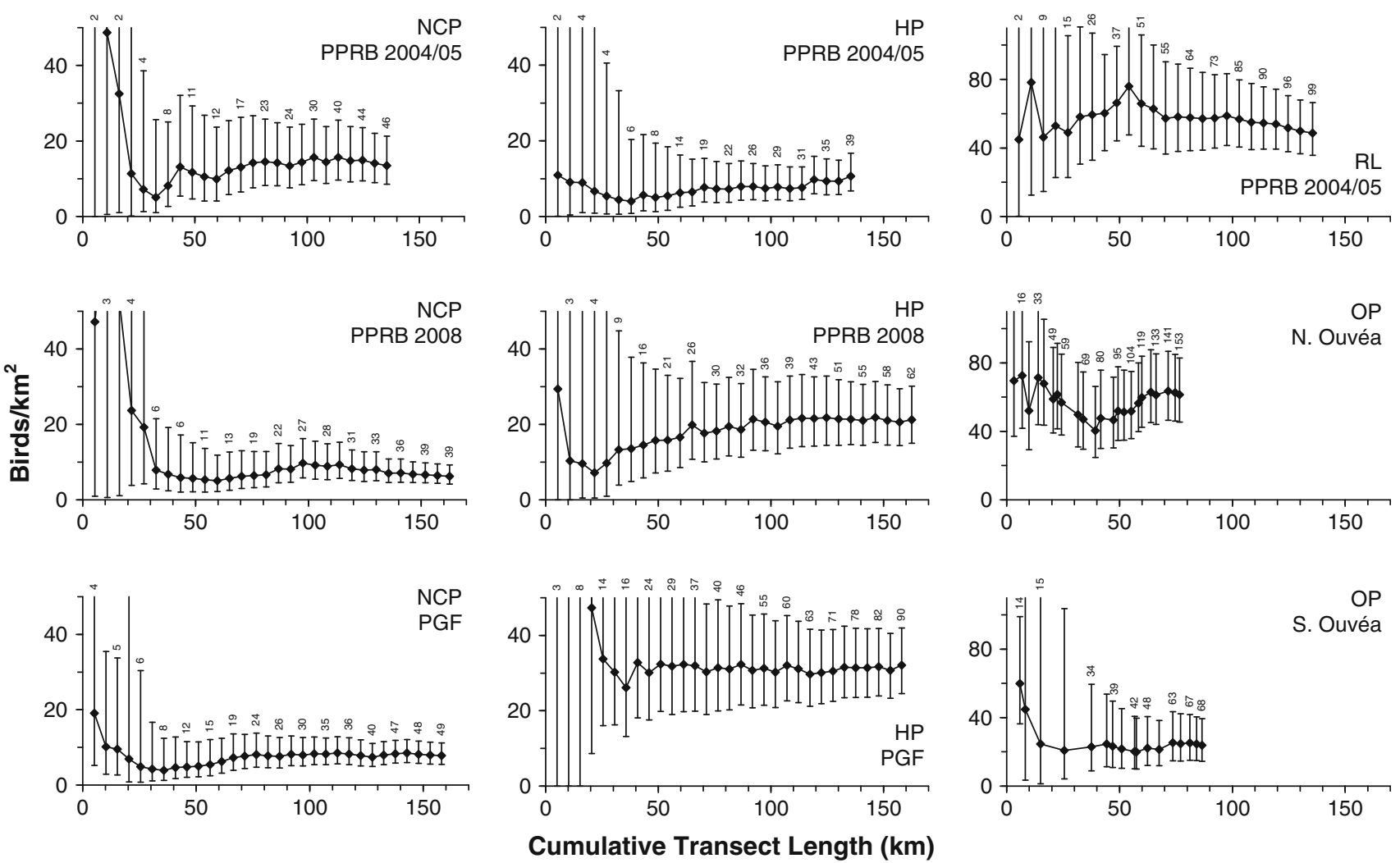

Fig. 3 Density (including $95 \%$ CIs) of New Caledonian Parakeets (NCP), Horned Parakeets (HP), Rainbow Lorikeets (RL), and Ouvéa Parakeets (OP) from line transect distance sampling, in relation to the cumulative length of transects surveyed at Parc Provincial de la

Vini australis (Avibase ID: 8FDE1AA233EB01BE) in relatively open habitats on the island of Futuna (J. Theuerkauf, unpublished data). Thus, it seems that even highly mobile, nectarivorous parrots can be surveyed with distance sampling, provided that the habitat structure does not greatly limit visibility.

\section{Point transects versus line transects}

Having experimented with both point and line transect surveys, we consider the former method to be less appropriate for estimating parakeet densities in New Caledonia. One of the main drawbacks of point transect distance sampling is that birds are excluded if they are detected while observers are travelling between points (Thomas et al. 2002). This can result in a critical loss of information for rare species, like the parakeets of New Caledonia. Despite walking briskly between points, we only spent approximately $60 \%$ of the total time counting at points, with the rest of the time spent travelling between points. While it is possible to study a larger area in a shorter amount of time with point transects, this is only achievable if observers move quickly between points.
Rivière Bleue (PPRB), Parc des Grandes Fougères (PGF), and on North and South Ouvéa. Digits above CIs represent the cumulative number of observations recorded

Point transect surveys have been suggested as an alternative method to consider if there are difficulties carrying out line transects due to dense vegetation, primarily because it is easier to reach a point than to navigate along a line in difficult terrain (Buckland et al. 1993, 2008). This may be worthwhile considering if the location and size of clusters can be estimated with some certainty from afar (e.g. from a vantage point overlooking the canopy). However, any errors that occur will become squared during density calculations, therefore accuracy is particularly important during point transect surveys (Marsden 1999). In order to obtain accurate distances one must be able to identify exactly where the bird is located, and in dense vegetation this may only be possible by searching for birds and measuring distances. We found that it was easier to measure perpendicular distances along a transect line than it was to measure straight-line distances from a point in the rainforest.

After realising the disadvantages of point transect surveys, we decided to abandon this method. Because of this, and the fact that we only sampled point transects in the afternoon, we are unable to compare the two methods in terms of accuracy or precision. However, other studies 

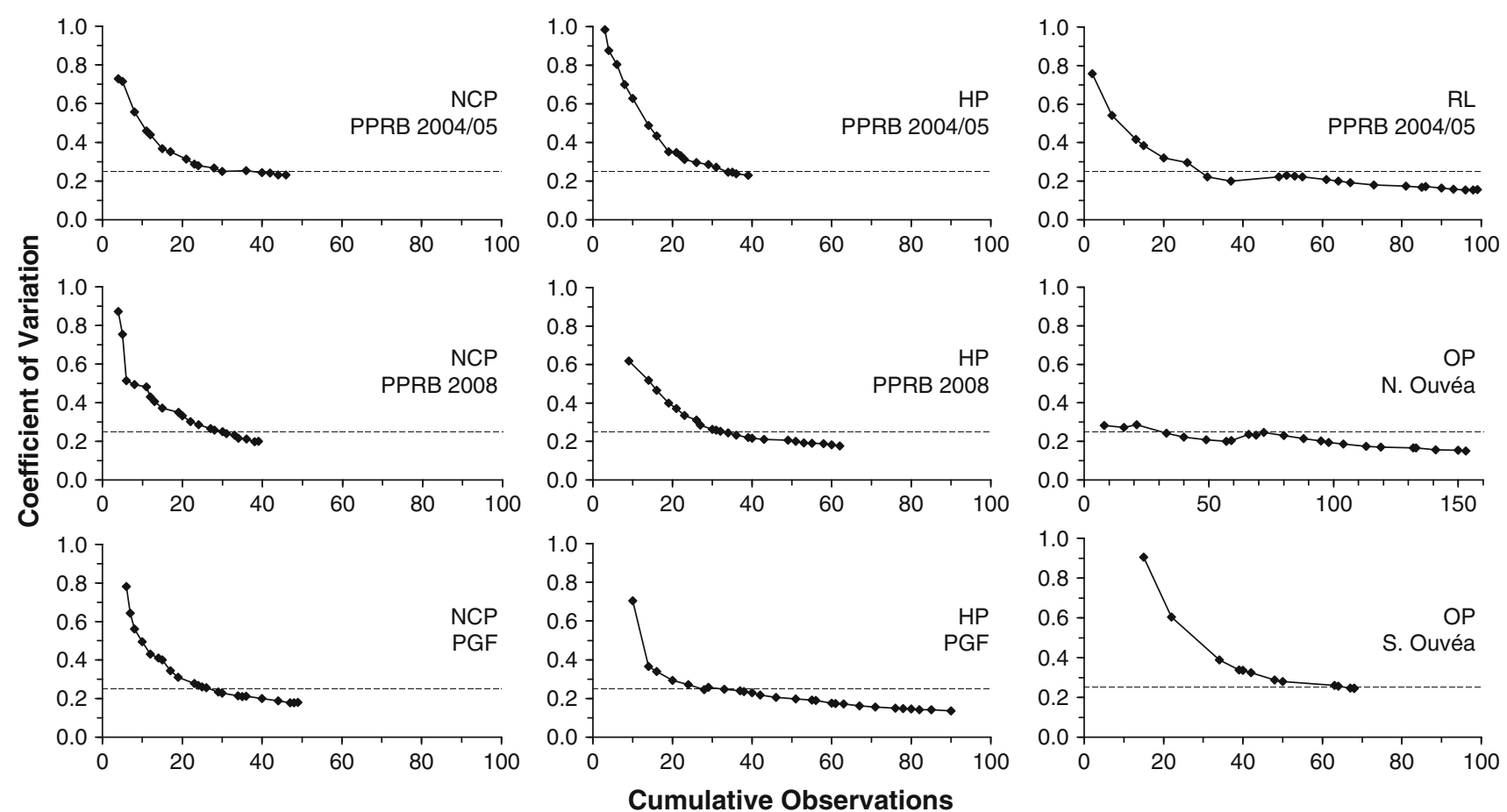

Fig. 4 Relationship between the coefficient of variation (CV) of density estimates and the number of New Caledonian Parakeets (NCP), Horned Parakeets (HP), Rainbow Lorikeets (RL) and Ouvéa Parakeets (OP) observed during line transect distance sampling at

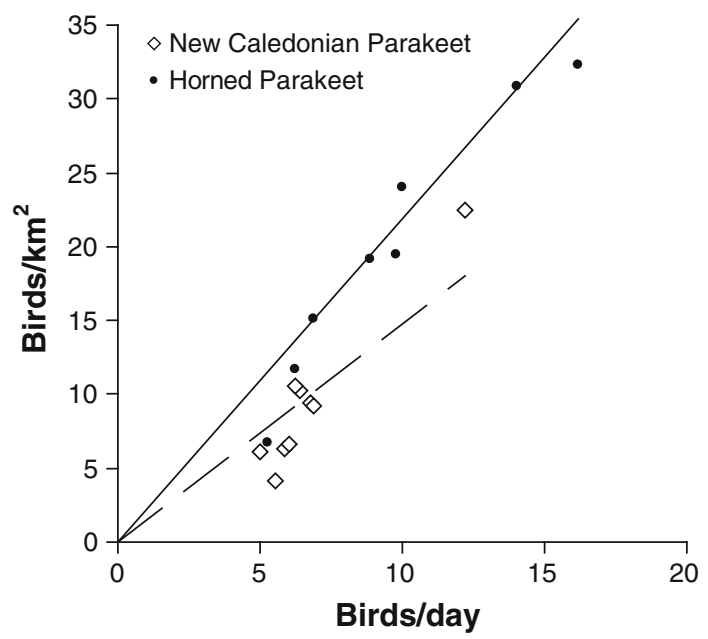

Fig. 5 Correlation between densities (birds $/ \mathrm{km}^{2}$ ) and encounter rates (birds/day) of New Caledonian Parakeets (dashed line; $r=0.88$; $P<0.001$ ) and Horned Parakeets (continuous line; $r=0.95$; $P<0.001)$ based on surveys at Parc Provincial de la Rivière Bleue and Parc des Grandes Fougères from 2004 to 2009

have shown that point transects are more biased than line transects (e.g. Raman 2003; Buckland 2006; Cassey et al. 2007; Gale et al. 2009). Line transects should also produce more precise estimates than point transects given the same amount of effort (Casagrande and Beissinger 1997). In
Parc Provincial de la Rivière Bleue (PPRB), Parc des Grandes Fougères (PGF), and on North and South Ouvéa. The dashed horizontal line represents a reference $\mathrm{CV}$ of 0.25

order to obtain similar levels of precision, the sample size of point transect surveys should be approximately $25 \%$ larger than that of line transect surveys (Buckland et al. 1993). Point transect surveys typically require a large number of points to obtain reliable data about uncommon species (Gale and Thongaree 2006), and are probably better suited to studying species that occur at higher densities (Greene et al. 2010), or for studying many species at once (Barraclough 2000), as it is easier to focus on the task of recording detections from a fixed point (Buckland et al. 2008). To maximise the efficiency of surveys, we recommend the use of line transects for estimating parakeet densities in New Caledonia. Point transect surveys might be a useful alternative for surveying Rainbow Lorikeets because the inefficiencies associated with this method are probably irrelevant when surveying such a common species.

\section{Assessing distances and flock sizes}

Estimating numbers and distances by ear can be imprecise (Hutto and Young 2003; Alldredge et al. 2007b), and yet such estimates are commonly used in distance sampling (e.g. Marsden 1999; Marsden et al. 2000; Jepson et al. 2001; Marsden and Pilgrim 2003; Gale and Thongaree 2006). To compensate for this imprecision, estimates are occasionally assigned to specific distance intervals in the 
Table 3 Densities $\left(D\right.$; birds $/ \mathrm{km}^{2}$ ) from line transect distance sampling and average encounter rates ( $E$; birds/day) of parakeets (including $95 \%$ confidence intervals) at Parc Provincial de la Rivière Bleue (PPRB) and Parc des Grandes Fougères (PGF)

\begin{tabular}{llcc}
\hline Site & Index & New Caledonian Parakeet & Horned Parakeet \\
\hline PPRB 2004/05 & $D$ & $13.5(8.6-21.3)$ & $10.7(6.8-16.8)$ \\
& $E$ & $7.9(5.4-10.4)$ & $5.9(4.0-7.8)$ \\
& $K$ & $1.7(1.3-2.1)$ & $1.8(1.4-2.2)$ \\
PPRB 2008 & $D$ & $6.2(4.2-9.2)$ & $21.3(15.0-30.1)$ \\
& $E$ & $6.6(4.3-8.9)$ & $8.2(6.1-10.3)$ \\
PGF & $K$ & $0.9(0.8-1.1)$ & $2.6(2.3-2.9)$ \\
& $D$ & $7.8(5.5-11.2)$ & $32.1(24.6-42.0)$ \\
& $E$ & $6.3(5.0-7.6)$ & $13.9(11.3-16.5)$ \\
Pooled & $K$ & $1.2(1.1-1.4)$ & $2.3(2.1-2.5)$ \\
\hline
\end{tabular}

The conversion between absolute densities and daily encounter rates is achieved using coefficient $K=D / E$

field (Buckland et al. 1993). However, this approach may lead to errors if detections end up in the wrong interval, especially near the transect line. In view of the difficulty in estimating distances and flock sizes in dense rainforests, we recommend tracking down birds whenever possible, so that individuals can be counted and distances can be accurately measured. In this study, we only estimated the location of birds that we were unable to see, and in most of these cases, we were still able to take measurements from where the calls came from. These occasional estimates are unlikely to have a considerable effect on the resulting density because the potential for distance estimation error is low near the transect line, and distant birds have little influence on density estimates.

Some studies suggest that it may be possible to achieve relatively robust density estimates despite a high dependence upon aural cues (e.g. Gale et al. 2009). Although we did not calculate the degree of imprecision associated with estimating distances, this could be accomplished by measuring and estimating distances simultaneously. If bias is systematic, an estimate-correction factor could also be calculated, based on the average degree of error associated with distance estimation (Buckland et al. 1993). Hence, whenever distances cannot be measured, the correction factor could be used to adjust estimates accordingly. Distance estimation errors can potentially be reduced further by employing several well-trained observers, rather than just one (Marsden 1999). When multiple observers are present, tasks can be shared and distances can be measured more easily. Furthermore, one observer can remain on the transect line while the other is confirming the location of detections, which is useful to maximise the probability of detecting birds near the line.

One of the underlying assumptions associated with distance sampling is that individuals are detected at their initial location (Buckland et al. 1993). The ability to meet this assumption comes into question with mobile species.
For example, if parrots fly towards or away from an observer, this can affect detection distances, and may result in biased density estimates. A low detection frequency close to the observer is suggestive of bias, either due to evasive bird movement, or failure to detect birds near the transect line (Buckland et al. 1993; Casagrande and Beissinger 1997). Although the lack of habitat above the road at PPRB may have reduced our ability to detect individuals near the transect line, we compensated for this during the analysis by shifting the transect line to the edge of the road. Having done so, the resulting fall-off in detection frequencies (Fig. 2) suggests that there was minimal movement prior to detection (Buckland et al. 1993; Marsden 1999). Parakeets were usually perched up high in the treetops, and we had no problem approaching them during searches, so we have no reason to believe that birds flew away as we advanced along the transect line. Also, the height of parakeets did not appear to influence detectability as detections were normally distributed with respect to height.

During prolonged searches, there is a greater chance that birds will leave their original location, and possibly even enter or exit the study area. Additionally, as distances increase, estimation errors are more likely to result from variations in the terrain (e.g. hills). Observers should therefore focus on locating birds close to the transect line instead of spending time searching for distant birds (Ekblom 2010). This should help to ensure that the probability of detecting birds close to the transect line is high, which is fundamentally important for distance sampling (Buckland et al. 1993; Marsden 1999). In some tropical forests, it is considered acceptable to focus on the nearest $30 \mathrm{~m}$ from the transect line (Buckland et al. 2008), and in the forests of Papua New Guinea, a search radius of $50 \mathrm{~m}$ was used to survey parrots and hornbills (Marsden and Pilgrim 2003), as well as cockatoos (Marsden et al. 2001). In order to minimise the effort expended searching for parrots in 
future surveys in New Caledonia, observers should concentrate on locating birds within approximately $50-70 \mathrm{~m}$ of the transect line. The vast majority $(96 \%)$ of the birds detected in this study were within $50 \mathrm{~m}$ of the transect line, and birds located farther away had very little impact on densities.

We rarely needed to estimate flock sizes in our study because we searched for any birds heard during surveys. Even when we estimated distances, we were usually close enough to have a good idea of how many birds were present. However, if aural detections are frequent, it may be necessary to compensate for instances where flock sizes are unknown. This can be accomplished by substituting the average flock size from visual detections for the unknown flock size (Marsden 1999; Marsden et al. 2000; Lee and Marsden 2008).

\section{Birds in flight}

As previously noted, birds can pose problems in distance sampling due to their high mobility. However, as long as their movement is not in response to observer presence, and their average speed is slow in relation to the observer, then bias is likely to be small (Buckland et al. 1993, 2001, 2008). Parakeets in New Caledonia spend most of their time in the canopy and typically cover relatively short distances during flight, so it is often possible to track them through forest (Legault et al. 2011). Therefore, records of flying parakeets are unlikely to generate substantial bias in density estimates, provided that line transects are used. Rainbow Lorikeets fly much farther and faster than parakeets, often in response to the availability of flowering or fruiting plants (Franklin and Noske 1999; Higgins 1999). Thus, including observations of Rainbow Lorikeets in flight could potentially result in an overestimate of density if many are just passing through the study area. Achieving realistic density estimates may therefore be difficult for this species, and a different strategy may be required to deal with the high proportion of birds observed in flight. Ideally, the distance to flying birds should be recorded when they are perpendicular to the observer (Buckland et al. 2001, 2008). However, it can be difficult to do this accurately in dense rainforests, and some birds are likely to either be lost from view before reaching this point, or only spotted afterwards. Marsden (1999) provides an alternative means of compensating for birds detected in flight, which is based on the average proportion of time that a particular species spends flying versus perching. Marsden (1999) used this method to adjust point count density estimates of Rainbow Lorikeets, but it is also applicable to line transect surveys (Buckland et al. 2001, 2008).

In general, we recommend that observers record birds in flight during surveys, as these records can always be omitted later. The decision to include, exclude, or compensate for flying birds in density estimates should be based on the habits of the particular species under study. To ignore birds in flight without taking this into consideration may lead to an underestimate of density, and could make it more difficult to estimate populations of rare or cryptic species.

Path width

If possible, line transect surveys should be carried out along straight, random lines (Buckland et al. 1993, 2001, 2008). Unfortunately, this is not practical in some environments, such as tropical rainforests, where the terrain often makes it difficult to maintain a steady pace, and one's ability to hear birds may be reduced by the rustling of vegetation while walking. As trails and dirt roads provide access to many remote areas in New Caledonia, we were interested in establishing whether they could be used for surveying parrots. Although paths are not representative of the landscape (Ellingson and Lukacs 2003), they are unlikely to affect the distribution of parrots unless they are so wide that they create considerable disturbances in the surrounding habitat (Hutto et al. 1995). Furthermore, it should not be assumed that all birds are attracted or deterred by paths (Venturato et al. 2010).

Our results indicate that densities may be underestimated if surveys are carried out on roads, although this problem can be reduced by compensating for the width of the road during the analysis stage. The lack of vegetation above roads is of particular concern, as this means that only flying birds will be detected directly above the transect line. Large gaps in the canopy may also be a deterrent for parrots, especially for Horned Parakeets as they tend to avoid edges (Legault et al. 2012). Thus, in environments where it is not feasible to position transects randomly, it may be best to conduct surveys along narrow trails, where there is minimal vegetation loss or disturbance.

\section{Survey period and parrot activity patterns}

Parrot activity varies over the course of a day, and this can influence the detectability of a species. Ideally, surveys should be carried out during periods of maximum detectability, and minimal bird movement (Marsden 1999). Foraging periods are good for this, as parrots tend to chatter while they feed, and they usually feed for a short while in one location (authors' observations). In order to standardise density estimates, we recommend that parrot surveys be undertaken from 0.5 to $3 \mathrm{~h}$ after dawn, or from 3 to $0.5 \mathrm{~h}$ before dusk. These are the main foraging periods for parrots in New Caledonia, and when most parrot encounters take place (Robinet et al. 2003; Legault et al. 2012). These 
survey times would likely be appropriate for other parrots in the tropics, which typically exhibit a bimodal pattern of activity (e.g. Hardy 1965; Pizo et al. 1997; Gilardi and Munn 1998).

Although densities of New Caledonian Parakeets appeared to be lower in the afternoon than in the morning, this may have been caused by small sample sizes. In comparison, there was little difference between morning and afternoon densities of Horned Parakeets. Nevertheless, the possibility that birds may be less active during certain periods of the day should be taken into consideration when planning surveys, as cryptic behaviour may decrease the probability of detecting birds near the transect line, and could potentially reduce density estimates. If time is not a factor, then it might be preferable to only survey transects at one period of the day, such as in the morning. However, by surveying transects during the afternoon as well as the morning, precise density estimates can be attained in half the number of days it would otherwise take. Additionally, surveying at different periods of the day can be useful for avoiding poor weather. Provided that the differences in detectability between survey periods are relatively minor, this should not generate biased density estimates due to the pooling robustness of the detection function (Buckland et al. 2004, 2008). Multiple-covariate distance sampling can also be used to compensate for such variations in detectability, and may be useful to increase the precision of density estimates (Marques et al. 2007).

When interpreting the results of our study, it is also important to consider the time of year when we conducted surveys. In 2004/2005, we surveyed transects from November to January, which coincides with the breeding season of parrots in New Caledonia (Hannecart and Létocart 1980, 1983), a time when most trees flower and fruit (Carpenter et al. 2003). However, in 2008 we carried out surveys from March to June. Therefore, any differences in densities between these two periods may be the result of seasonal variations in habitat selection. To avoid this problem, surveys should be conducted at the same location and time of year (Marsden 1999). We believe that the best time of the year to carry out surveys is during the breeding season, roughly from November to February, when parakeets are likely to remain near their nesting areas. Differences in observer ability can also bias density estimates (e.g. Norvell et al. 2003). However, observer turnover is unlikely to have been responsible for the observed variation in densities between seasons as encounter rates and densities were linearly correlated (Fig. 5). This potential source of error could be eliminated by using the same observers each year, or minimised through consistent training. Observer bias can also be reduced by randomly rotating observers between transects (e.g. Peres 1999).
Survey effort

As survey effort increases, more observations are recorded, and the precision of the density estimate usually improves. However, expending an excessive amount of effort to attain a modest increase in precision is an inefficient use of resources, and may be unacceptable if it delays conservation action. On the other hand, if the sample size is inadequate, then little information will be available in relation to density (Buckland et al. 1993). Our surveys provide an indication of the amount of effort that will be required to estimate parakeet densities elsewhere in New Caledonia. In most cases, we obtained stable density estimates with 40-50 observations, yet sites with particularly high densities (e.g. over $20 \mathrm{birds} / \mathrm{km}^{2}$ ) may require more. Additional effort will improve the precision of the estimate, and may be warranted at key monitoring sites. Buckland et al. (1993) indicate that a sample size of 40 may be adequate under certain circumstances, but generally recommend a sample size of at least $60-80$. Achieving such numbers in practice may require a substantial amount of time when studying uncommon or cryptic species. Even if samples are gathered over a long period, there is a possibility that the coefficients of variation will remain high due to the amount of spatial variation associated with species that occur at low densities. As conservation resources are often limited, correlating indices of abundance with absolute densities might provide an efficient alternative for monitoring population trends and estimating population sizes when distance sampling is not practical. Additional testing would be useful, however, as other studies suggest that such correlations may not hold up over time (e.g. Norvell et al. 2003).

In conclusion, we encourage the adoption of line transect distance sampling for surveying parakeet populations in New Caledonia, and believe that standardisation of survey techniques will facilitate comparison between different areas and time periods. Our suggestions may be useful to other researchers interested in estimating bird populations in tropical rainforests, and can be adapted to suit different species or environments.

Acknowledgments This study was part of the research project "Impact of introduced mammals and habitat loss on endemic birds of New Caledonia", done in cooperation with the Direction de l'Environnement (Province Sud, New Caledonia), which issued all permits for this study, and financed by the Loro Parque Fundación (Spain), Polish Ministry of Science and Higher Education (Grant 2P04F 001 29), Conservation des Espèces et Populations Animales (France), La Fondation Nature et Découvertes (France), Fonds für bedrohte Papageien-Zoologische Gesellschaft für Arten- und Populationsschutz (Germany), and doctoral grants from the University of Tasmania (to A. Legault) and Province Sud (to S. Rouys). Field work on Ouvéa was financed by the Province des Iles Loyauté (New Caledonia), the ASPO (New Caledonia), the Société Calédonienne d'Ornithologie (New Caledonia) and the British Birdwatching Fair (U.K.). We thank A. Barnaud, A. Bauma, S. Baoutuau, M.F. Barré, M. Broersen, 
M. Capoa, J.F. Chaouri, J.B. Dao, P. Dialla, O. Hebert, B. Michielsen, V. Mindia, T. Sanchez, B. Tangopi, C. Vanhoye, W. Wamo, B. Waneux, L. Wéa and A. Wétéwéa for their help during field work, and A. Richardson (University of Tasmania), F. Huettmann, T. Müller, and an anonymous reviewer for providing valuable feedback on the manuscript.

Open Access This article is distributed under the terms of the Creative Commons Attribution License which permits any use, distribution, and reproduction in any medium, provided the original author(s) and the source are credited.

\section{References}

Alldredge MW, Pollock KH, Simons TR (2006) Estimating detection probabilities from multiple-observer point counts. Auk 123:1172-1182

Alldredge MW, Pollock KH, Simons TR, Collazo JA, Shriner SA (2007a) Time-of-detection method for estimating abundance from point-count surveys. Auk 124:653-664

Alldredge MW, Simons TR, Pollock KH (2007b) A field evaluation of distance measurement error in auditory avian point count surveys. J Wildl Manage 71:2759-2766

Amar A, Amidon F, Arroyo B, Esselstyn JA, Marshall AP (2008) Population trends of the forest bird community on the Pacific island of Roto, Mariana Islands. Condor 110:421-427

Bächler E, Liechti F (2007) On the importance of $g(0)$ for estimating bird population densities with standard distance-sampling: implications from a telemetry study and a literature review. Ibis 149:693-700

Barraclough RK (2000) Distance sampling: a discussion document produced for the Department of Conservation. Department of Conservation, Wellington

Barré N, Theuerkauf J, Verfaille L, Primot P, Saoumoé M (2010) Exponential population increase in the endangered Ouvéa Parakeet (Eunymphicus uvaeensis) after community-based protection from nest poaching. J Ornithol 151:695-701

Bonnet de Larbogne L, Chazeau J, Tillier A, Tillier S (1991) Milieux naturels néo-calédoniens: la réserve de la Rivière Bleue. Zoologia Neocaledonica 2. Mém Mus Nat Hist Nat 149:9-17

Bregulla H (1993) Die Papageien Neukaledoniens. Gefiederte Welt 117:381-384

Buckland ST (2006) Point-transect surveys for songbirds: robust methodologies. Auk 123:345-357

Buckland ST, Anderson DR, Burnham KP, Laake JL (1993) Distance sampling: estimating abundance of biological populations. Chapman \& Hall, London

Buckland ST, Anderson DR, Burnham KP, Laake JL, Borchers DL, Thomas L (2001) Introduction to distance sampling: estimating abundance of biological populations. Oxford University Press, Oxford

Buckland ST, Anderson DR, Burnham KP, Laake JL, Borchers DL, Thomas DL (2004) Advanced distance sampling. Oxford University Press, Oxford

Buckland ST, Marsden SJ, Green RE (2008) Estimating bird abundance: making methods work. Bird Conserv Int 18:S91S108

Burnham KP, Anderson DR, Laake JL (1980) Estimation of density from line transect sampling of biological populations. Wildl Monogr 72:1-202

Carpenter RJ, Read J, Jaffré T (2003) Reproductive traits of tropical rain-forest trees in New Caledonia. J Trop Ecol 19:351-365

Casagrande DG, Beissinger SR (1997) Evaluation of four methods for estimating parrot population size. Condor 99:445-457
Cassey P, Craig JL, McArdle BH, Barraclough RK (2007) Distance sampling techniques compared for a New Zealand endemic passerine (Philesturnus carunculatus rufusater). N Z J Ecol 31:223-231

Chartendrault V, Barré N (2005) Etude du statut et de la distribution des oiseaux menacés de la Province Nord de Nouvelle-Calédonie. Institut Agronomique néo-Calédonien, New Caledonia

Chartendrault V, Barré N (2006) Etude du statut et de la distribution des oiseaux des forêts humides de la Province Sud de NouvelleCalédonie. Institut Agronomique néo-Calédonien, New Caledonia

Ekblom R (2010) Evaluation of the analysis of distance sampling data: a simulation study. Ornis Svec 20:45-53

Ellingson AR, Lukacs PM (2003) Improving methods for regional landbird monitoring: a reply to Hutto and Young. Wildl Soc Bull 31:896-902

Emlen J (1971) Population densities of birds derived from transect counts. Auk 88:323-342

Emlen J (1977) Estimating breeding season bird densities from transect counts. Auk 94:455-468

Farnsworth GL, Pollock KH, Nichols JD, Simons TR, Hines JE, Sauer JR (2002) A removal model for estimating detection probabilities from point-count surveys. Auk 119:414-425

Franklin DC, Noske RA (1999) Birds and nectar in a monsoonal woodland: correlations at three spatio-temporal scales. Emu 99:15-28

Gale GA, Thongaree S (2006) Density estimates of nine hornbill species in a lowland forest site in southern Thailand. Bird Conserv Int 16:57-69

Gale GA, Round PD, Pierce AJ, Nimnuan S, Pattanavibool A, Brockelman WY (2009) A field test of distance sampling methods for a tropical forest bird community. Auk 126:439-448

Gilardi JD, Munn CA (1998) Patterns of activity, flocking, and habitat use in parrots of the Peruvian Amazon. Condor 100:641-653

Gnam R, Burchsted A (1991) Population estimates for the Bahama Parrot on Abaco Island, Bahamas. J Field Ornithol 62:139-146

Goodman LA (1960) On the exact variance of products. J Am Stat Assoc 55:708-713

Greene T, Jones A, Dennis G, Sachtleben T (2010) Distance sampling to determine kaka (Nestor meridionalis septentrionalis) density within Waipapa Ecological Area, Pureora. N Z J Ecol 34:297-305

Gula R, Theuerkauf J, Rouys S, Legault A (2010) An audio/video surveillance system for wildlife. Eur J Wildl Res 56:803-807

Hahn P (1993) Anmerkungen zur Situation des Hornsittichs Eunymphicus cornutus auf Neukaledonien und Ouvéa. Papageien 6:189-192

Hannecart F, Létocart Y (1980) Oiseaux de Nouvelle Calédonie et des Iles Loyauté-Tome I. Cardinalis, Nouméa

Hannecart F, Létocart Y (1983) Oiseaux de Nouvelle Calédonie et des Iles Loyauté-Tome II. Cardinalis, Nouméa

Hardy JW (1965) Flock social behavior of the Orange-fronted Parakeet. Condor 67:140-156

Heydon MJ, Reynolds JC, Short MJ (2000) Variation in abundance of foxes (Vulpes vulpes) between three regions of rural Britain, in relation to landscape and other variables. J Zool 251:253-264

Higgins PJ (1999) Handbook of Australian, New Zealand and Antarctic Birds-Volume 4: Parrots to Dollarbird. Oxford University Press, Melbourne

Hutto RL, Young JS (2003) On the design of monitoring programs and the use of population indices: a reply to Ellingson and Lukacs. Wildl Soc Bull 31:903-910

Hutto RL, Hell SJ, Kelly JF, Pletschet SM (1995) A comparison of bird detection rates derived from on-road versus off-road point counts in northern Montana. In: Ralph CJ, Sauer JR, Droege S (eds.) Monitoring bird populations by point counts. USDA For Serv Gen Tech Rep PSW-GTR-149, Albany, USA 
IUCN (2011) IUCN red list of threatened species. Version 2011.2. www.iucnredlist.org. Accessed 5 February 2012

Jaffré T, Veillon J-M (1995) Structural and floristic characteristics of a rain forest on schist in New Caledonia: a comparison with an ultramafic rain forest. Bull Mus Natl Hist Nat, Paris, 4e sér, 9. Sect B Adansonia 4:201-226

Jepson P, Brickle N, Chayadin Y (2001) The conservation status of Tanimbar corella and blue-streaked lory on the Tanimbar Islands, Indonesia: results of a rapid contextual survey. Oryx 35:224-233

Johnson DH (2008) In defense of indices: the case of bird surveys. J Wildl Manage 72:857-868

Jones MJ, Linsley MD, Marsden SJ (1995) Population sizes, status and habitat associations of the restricted-range bird species of Sumba, Indonesia. Bird Conserv Int 5:21-52

Karubian J, Fabara J, Yunes D, Jorgenson JP, Romo D, Smith TB (2005) Temporal and spatial patterns of Macaw abundance in the Ecuadorian Amazon. Condor 107:617-626

Layard EL, Layard ELC (1882) Notes on the avifauna of New Caledonia, with remarks by the Rev. Canon Tristram. Ibis 24:493-546

Lee DC, Marsden SJ (2008) Adjusting count period strategies to improve the accuracy of forest bird abundance estimates from point transect distance sampling surveys. Ibis 150:315-325

Legault A, Chartendrault V, Theuerkauf J, Rouys S, Barré N (2011) Large-scale habitat selection by parrots in New Caledonia. J Ornithol 152:409-419

Legault A, Theuerkauf J, Rouys S, Chartendrault V, Barré N (2012) Temporal variation in flock size and habitat use of parrots in New Caledonia. Condor 114 (in press)

Marques TA, Thomas L, Fancy SG, Buckland ST (2007) Improving estimates of bird density using multiple-covariate distance sampling. Auk 124:1229-1243

Marsden SJ (1999) Estimation of parrot and hornbill densities using a point count distance sampling method. Ibis 141:377-390

Marsden SJ, Pilgrim JD (2003) Factors influencing the abundance of parrots and hornbills in pristine and disturbed forests on New Britain, PNG. Ibis 145:45-53

Marsden SJ, Symes CT (2006) Abundance and habitat associations of parrots at a hillforest site in Papua New Guinea. Pac Conserv Biol 12:15-21

Marsden SJ, Whiffin M, Sadgrove L, Guimarães P Jr (2000) Parrot populations and habitat use in and around two lowland Atlantic forest reserves, Brazil. Biol Conserv 96:209-217

Marsden SJ, Pilgrim JD, Wilkinson R (2001) Status, abundance and habitat use of Blue-eyed Cockatoo Cacatua ophthalmica on New Britain, Papua New Guinea. Bird Conserv Int 11:151-160

Marsden SJ, Symes CT, Mack AL (2006) The response of a New Guinean avifauna to conversion of forest to small-scale agriculture. Ibis 148:629-640

Meyers JM (1994) Improved capture techniques for psittacines. Wildl Soc Bull 22:511-516

Nichols JD, Hines JE, Sauer JR, Fallon FW, Fallon JE, Heglund PJ (2000) A double-observer approach for estimating detection probability and abundance from point counts. Auk 117:393-408

Norvell RE, Howe FP, Parrish JR (2003) A seven-year comparison of relative-abundance and distance-sampling methods. Auk 120:1013-1028

Pain DJ, Martins TLF, Boussekey M, Diaz SH, Downs CT, Ekstrom JMM, Garnett S, Gilardi JD, McNiven D, Primot P, Rouys S, Saoumoé M, Symes CT, Tamungang SA, Theuerkauf J, Villafuerte D, Verfailles L, Widmann P, Widmann ID (2006) Impact of protection on nest take and nesting success of parrots in Africa, Asia and Australasia. Anim Conserv 9:322-330

Peres CA (1999) General guidelines for standardizing line-transect surveys of tropical forest primates. Neotrop Primates 7:11-16
Pizo MA, Simão I, Galetti M (1997) Daily variation in activity and flock size of two parakeet species from southeastern Brazil. Wilson Bull 109:348-351

Raman TR (2003) Assessment of census techniques for interspecific comparisons of tropical rainforest bird densities: a field evaluation in the Western Ghats, India. Ibis 145:9-21

Reynolds RT, Scott JM, Nussbaum RA (1980) A variable circularplot method for estimating bird numbers. Condor 82:309-313

Rivera-Milán FF, Collazo JA, Stahala C, Moore WJ, Davis A, Herring G, Steinkamp M, Pagliaro R, Thompson JL, Bracey W (2005) Estimation of density and population size and recommendations for monitoring trends of Bahama parrots on Great Abaco and Great Inagua. Wildl Soc Bull 33:823-834

Robinet O, Barré N, Salas M (1996) Population estimate for the Ouvéa Parakeet Eunymphicus cornutus uvaeensis: its present range and implications for conservation. Emu 96:151-157

Robinet O, Craig JL, Chardonnet L (1998) Impact of rat species in Ouvéa and Lifou (Loyalty Islands) and their consequences for conserving the endangered Ouvéa Parakeet. Biol Conserv $86: 223-232$

Robinet O, Bretagnolle V, Clout M (2003) Activity patterns, habitat use, foraging behaviour and food selection of the Ouvéa Parakeet (Eunymphicus cornutus uvaeensis). Emu 103:71-80

Rodriguez-Estrella R, Mata E, Rivera L (1992) Ecological notes on the Green Parakeet of Isla Socorro, Mexico. Condor 94:523-525

Rosenstock SS, Anderson DR, Giesen KM, Leukering T, Carter MF (2002) Landbird counting techniques: current practices and an alternative. Auk 119:46-53

Rouys S, Theuerkauf J (2003) Factors determining the distribution of introduced mammals in nature reserves of the southern province, New Caledonia. Wildl Res 30:187-191

Sandercock BK, Beissinger SR (2002) Estimating rates of population change for a neotropical parrot with ratio, mark-recapture and matrix methods. J Appl Stat 29:589-607

Simon JC, Pratt TK, Berlin KE, Kowalsky JR, Fancy SG, Hatfield JS (2002) Temporal variation in bird counts within a Hawaiian rainforest. Condor 104:469-481

Spaggiari J, Chartendrault V, Barré N (2007) Zones importantes pour la conservation des oiseaux de Nouvelle-Calédonie. SCO and BirdLife International, Nouméa

Theuerkauf J, Rouys S, Jędrzejewski W (2008) Detectability and disappearance of ungulate and hare faeces in a European temperate forest. Ann Zool Fenn 45:73-80

Theuerkauf J, Rouys S, Mériot JM, Gula R, Kuehn R (2009) Cooperative breeding, mate guarding, and nest sharing in two parrot species of New Caledonia. J Ornithol 150:791-797

Thomas L, Buckland ST, Burnham KP, Anderson DR, Laake JL, Borchers DL, Strindberg S (2002) Distance sampling. In: ElShaarawi AH, Piegorsch WW (eds) Encyclopedia of environmetrics. Wiley, Chichester, pp 544-552

Thomas L, Buckland ST, Rexstad EA, Laake JL, Strindberg S, Hedley SL, Bishop JRB, Marques TA, Burnham KP (2010) Distance software: design and analysis of distance sampling surveys for estimating population size. J Appl Ecol 47:5-14

Thompson WL (2002) Towards reliable bird surveys: accounting for individuals present but not detected. Auk 119:18-25

Venturato E, Cavallini P, Dessi-Fulgheri F (2010) Are pheasants attracted or repelled by roads? A test of a crucial assumption for transect censuses. Eur J Wildl Res 56:233-237

Walker JS, Cahill AJ (2000) Population size and status of the Yellowbreasted Racquet-tail Parrot Prioniturus flavicans. Bird Conserv Int 10:131-136

Whitman AA, Hagan JM III, Brokaw NVL (1997) A comparison of two bird survey techniques used in a subtropical forest. Condor 99:955-965 